\title{
Research on How to Promote the Development of Career Guidance in Colleges and Universities
}

\author{
Yan Wang \\ Zhengzhou Institute of Technology, Zhengzhou, Henan, 450044
}

Keywords: Colleges and Universities; Vocational Guidance; Development Strategy

\begin{abstract}
Career guidance plays an important role in the employment of students and even the development of colleges and universities. This paper starts from the importance of vocational guidance to the development of colleges and universities. By comprehensively analyzing the current situation and existing problems of vocational guidance in colleges and universities, this article defines the goal of vocational guidance in colleges and universities and the policy of promoting career guidance in colleges and universities. It proposes to establish a reasonable and scientific career guidance system which is conducive to promoting the construction of higher vocational guidance
\end{abstract}

\section{The Content and Significance of Career Guidance in a University}

The Meaning of College Vocational Guidance. Career guidance comes from the objective needs of the society. It is born with the development of social economy. With the deepening of theoretical research, its content is continuously enriched and developed. Career guidance in colleges and universities is an effective link between social needs and individual needs of students. It is a process by which career guidance workers in colleges and universities guide young students to choose their prospective careers properly through certain means and methods. It guides college students to fully understand find interest, obtain employment information, and ultimately make career decisions. Career guidance in colleges and universities includes guiding students to carry out career planning in accordance with the needs of social and economic development and combining with their own characteristics, and assisting students in job testing, career counseling and career guidance.

According to the report of "The Strategy of Career Guidance for the 21st Century" issued by the International Association for Educational and Vocational Guidance, scientific career guidance varies from person to person. Different personal talents, family environment and socio-economic needs have far-reaching effects on future career choices. Students make a specific choice according to the actual situation. According to the actual development of colleges and universities, training objectives and standards of graduation students to develop occupational guidance work plan, design training courses to enable students to learn how to find suitable jobs for their own development and rapid integration into the work environment. The report also pointed out that vocational guidance should not be limited to only providing employment information services to students. The employment guidance department of colleges and universities should also provide students with employment guidance services to help students establish a correct mentality of seeking employment and cultivate job-seeking abilities.

The Significance of College Employment Guidance. The role of vocational guidance in higher education on college education. In the popularization of higher education, the reform of higher education has been gradually deepened, the socialist market economy has been perfected and the science has developed rapidly. The contradiction between the current situation of higher education and that incompatible with social development has become increasingly prominent. The challenges facing higher education institutions are obviously greater than the opportunities.

There is an objective contradiction between the rapid increase of college enrollment policy and the number of university graduates and the increasingly severe employment situation in our country. 
The employment of college students is particularly prominent. Therefore, the effectiveness of career guidance in colleges and universities directly affects the employment status of our society. At the same time, the success of guiding the work can also be directly reflected in the employment rate of university students in the current year. Effective development of vocational guidance in higher education institutions will break through the existing employment bottlenecks and ease the crisis of "graduation or unemployment" carrying on the theoretical research on vocational guidance work in colleges and universities is conducive to promoting the education reform in colleges and universities.

Career guidance work in colleges and universities should solve the problems of students and society and alleviate social conflicts. At present, the development model of higher education in our country is changing towards "popularization". Faced with the policy of enlarging enrollment in higher education institutions in recent years and the state's policy of delaying retirement, more and more college graduates are facing increasingly serious employment problems. The number of college graduates and social demand was negatively correlated. Therefore, carry out professional career planning and employment service training courses for undergraduates can help graduates to find employment direction and achieve employment smoothly during the employment season. The purpose of college career guidance for college students is not only to improve the employment rate of colleges and universities. The most important thing is to help students solve employment problems effectively. The employment of college students is related to the healthy and sustainable development of higher education in our country and the social progress and harmony. In the process of employment guidance in colleges and universities, we should establish a positive outlook on employment for students, promote the diversification of occupations, and solve the social employment problems in the long run.

\section{Status Quo and Existing Problems of Vocational Guidance Work in Second Colleges and Universities}

The Status Quo and Characteristics of College Career Guidance. College career guidance more and more specialized. In the process of vocational employment guidance in colleges and universities, it is necessary to establish a positive outlook on employment of students and promote the diversification of occupations in order to solve the social employment problems in the long run. Therefore, carry out career planning and employment guidance courses, we must take the scientific values as a guide, comprehensive sociology, psychology and other related theoretical knowledge, career guidance can make more and more professional, vocational college career guidance in professional quality obtained enhance. As an independent science, the establishment of a professional career guidance team will greatly enhance the efficiency of career guidance, and use of comprehensive theoretical knowledge to solve practical problems of students.

College career guidance is more and more professional. In recent years, employment guidance in colleges and universities make the professional direction. Most colleges and universities have set up independent employment guidance offices, and even some departments also have professional employment guidance teachers. For example, Siyasi International College of Zhengzhou University, each faculty year-level professional responsible teachers have psychology background or minor psychology courses, at the same time part-time employment guidance teacher, this employment guidance work arrangements will be students employment guidance and professional The connection between students' professional learning and career development will help to reduce the emergence of problems in employment guidance such as employment difficulties and other issues. At the same time, different grades are equipped with vocational guidance teachers will help to develop students' career planning awareness and improve employment awareness. Followed by specialized agencies in the provincial and municipal talent agencies also have professional guidance agencies, professional teachers to carry out vocational guidance and training, and employment guidance for the upcoming employment counseling services.

Career guidance is more and more diversified in colleges and universities. Until today, with the progress of science and technology, people gradually become more diversified in the way of 
learning and living. Application in vocational guidance in colleges and universities, you can gradually extend the traditional form of face-to-face teaching network open class teaching methods. The lectures can also be extended by ordinary lectures to field trips, experiential teaching activities such as simulated internships combined mode. The diversification of college vocational guidance forms can increase the interest of the course, fully mobilize the enthusiasm and initiative of the students to participate, and make the accumulated experience more profound, especially in the securities and stock classes, which are highly employable, only through theoretical courses career guidance is not enough. Secondly, with the emergence of occupational assessment analysis software, colleges and universities can make professional career assessment analysis reports and career development plans for students through the Internet, and then use the convenience of the network to communicate directly with students, which can be very large. The degree of saving time and space costs, so that students can keep abreast of professional trends, so that students quickly recognize themselves.

The Problems of College Career Guidance. Since 2002, the Ministry of Education has demanded that universities and colleges establish and improve graduates' employment guidance service institutions, both in terms of office conditions and in the guidance of personnel, and so on. After decades of development, the employment guidance work in colleges and universities has developed rapidly. However, there are still many problems in the process of development.

The concept of career guidance is not clear and the organizational structure is not perfect. Since the reinstatement of the college entrance examination, our country has implemented the policy of program distribution for a long period of time. Especially in the initial stage of social economy, all kinds of high-quality talents are in urgent need of the society. The schools are responsible for transferring graduating college graduates to various supply and demand units. It largely inhibited the development of career guidance in our country, led to the late start of career guidance in our country and the weak foundation of theoretical research.

At present, the job guidance of colleges and universities in our country is only limited to the training and service for graduates, ignoring the importance of career planning training for the entire university learning stage, which has greatly restricted the scope and content of vocational guidance, resulting in vocational guidance work in colleges and universities in an inefficient state. Second, the employment guidance departments of colleges and universities not fully functions, institutional settings unreasonable, the focus of work is devoted to the release of employment information and employment policy advocacy, ignoring the daily student career planning and guidance services.

There is a single form of career guidance, curriculum lag. Most of the teaching methods in colleges and universities in our country are still taught in the traditional way, and the setting of practice courses is far lower than that in other countries. This has led to the emphasis placed on the theoretical research of the curriculum in colleges and universities in our country. Therefore, the social adaptability of college graduates in our country generally weaker. Especially in the socio-economic development to a certain extent, more and more advanced science and technology today, a single theoretical teaching method can no longer meet the needs of social development, purely theoretical research talent will also be gradually eliminated by the economy and society. Therefore, the diversification of curriculum design is not only the requirement of the long-term development of the school, but also the challenge that the society initiates to the university. Vocational guidance courses should be more a combination of theory and practice courses, but at present our country college career guidance work, the theory of teaching is more common.

Single guidance not only cannot match the real-time employment guidance, but also limits the employment guidance of the scope of the scope and breadth of the content, making career information cannot be promptly communicated, the lack of scientific basis for career planning and management of graduates; It does not take into account the training of other related courses, such as the qualifications of graduates, necessary vocational skills and psychological counseling. In addition, the design of vocational guidance courses in colleges and universities lacks scientific planning basis and the courses are set up later, resulting in many college students lacking in job employment awareness and receiving insufficient guidance and training. They are not familiar with 
the career choice process and cannot acquire scientific employment methodology and employment skills. Students often use "indoctrination" one-way classroom teaching methods, lack of contact with the actual and individual guidance, case analysis is not enough for some advanced vocational guidance, methods due to the conditions of the failure to fully draw on and use, It cannot properly link vocational guidance with individual career development needs so that students cannot see the benefits brought about by professional guidance and cannot fully mobilize the enthusiasm of student participation.

A serious shortage of vocational guidance teachers and the overall quality needs to be improved. At present, the vast majority of colleges and universities are equipped with full-time employment guidance and service teachers. Despite the full employment of staff and the timely issuance of employment information and policies, there are still quite serious difficulties in employment guidance. In particular, some colleges and universities are eager to improve the employment rate of colleges and universities, thus neglecting the career guidance of the entire school. Second, the majority of college employment guidance teachers from the administrative positions or political workers, they lack the professional guidance training, do not have professional guidance professional knowledge and professional qualifications, different professional and career design cannot make an accurate match, so college job Instructors professional quality is very lacking. In addition, there is a serious imbalance between the number of graduates and the number of graduates engaged in employment guidance in colleges and universities all over the country. The proportion of some colleges and universities is much lower than the 1: 500 stipulated by the state. Such data proportion will result in inefficiency and unsatisfactory employment guidance in higher education institutions emergence of such issues. At present, the college career guidance teachers mainly consist of three parts: one is the full-time teachers in moral education course; the second is engaged in employment or student work of ideological and political workers; the third is the temporary employment of human development companies or large and medium-sized enterprise human resources experts.

\section{Countermeasures Timeliness Research on the Healthy Development of Career Guidance in Colleges and Universities}

The Carry Out of Vocational Guidance Needs a Variety of Training Courses to Be Synchronized. When setting up a career guidance department or an employment guidance office, colleges and universities should take into account the clear division of functions and the quantification of responsibilities. A sound university career guidance department should set up professional planning and research offices, counseling offices, vocational skills training offices and employment promotion offices and other basic functions of the office. In particular, the career planning office and the job guidance publicity office work complement each other. In order to avoid graduates blind employment and unclear employment concept during the graduation season, many colleges and universities design the career planning curriculum in front of the design, employment Guidance course design in the post. The new career planning courses help college students to make adequate planning for their careers with sufficient university time and improve their career planning in the continuous learning process. Until the senior year employment season, colleges and universities according to the actual situation of student career planning for their different types of employment guidance, this curriculum design will enable college students to make full employment preparation, but also make college students "graduate or unemployed" phenomenon gradually reduce.

College Career Guidance and Forms of Guidance Are Diversified. From the traditional lecture-based teaching methods to the development of extra-curricular, colleges and universities should take advantage of talent and actively outstanding industrial enterprises and provinces and cities to establish good relations of cooperation through the partnership between the theoretical knowledge of the classroom and field exercises cannot only impress students, you can for the cooperation unit directly deliver excellent standard talent. Second, career guidance can also be developed from traditional face-to-face conversations to new media on the Internet, such as online 
job surveys and remote real-time interactions. Through the network of occupational questionnaires can save costs, you can also break the space constraints. Colleges and universities should design a set of professional career guidance questionnaire, after the questionnaire is completed through a preliminary analysis of the types of students roughly classified, and give a preliminary analysis and guidance recommendations, after the questionnaire, career guidance teachers should be based on the questionnaire analysis for students to organize professional career guidance services, according to the specific circumstances of students and analysis of results to help students improve career planning and design, and provide follow-up employment guidance services for students in need.

Cultivate Professional Career Guidance Teachers and Carry out Professional Guidance. Practice has proved that vocational guidance to solve the employment of university students is very important to help, professional and responsible career guidance for job seekers or employers are very helpful, so as soon as possible to improve the efficiency of career guidance, we must work hard Improve the overall quality of employment guidance teachers, make employment guidance more professional and professional. At present, most of the college career guidance staff in our country have already taken part in the vocational skill appraisal and obtained relevant qualification certificates. However, as far as students' reflection is concerned, these teachers do not have good instructional content for career guidance training and career guidance for college graduates match. It is suggested that all colleges and universities employ a career guidance team to carry out professional training for school employment staff and design a career guidance training program suitable for school development based on the school development so as to improve the staffing of the employment guidance and working department and set up a person responsible for each job function, training, career planning, employment guidance and employment promotion work are separated, so that the work efficiency of career guidance in colleges and universities is more quantified and a more complete and scientific working system is formed.

The career guidance will always run through the whole process of college education, strengthen the responsibility system for the goal, set up a series of vocational education courses, the entire employment education. For example, many colleges and universities now offer careers planning and careers for undergraduates, but the teaching arrangements are not the same for each school. The plans and schedules are not the same. Some senior students will make arrangements but I do think that career guidance education should be provided from the very first year onwards. Only in this way can college students better understand the professional employment prospects they have learned, employment planning and employment space and make them better. Choose your own profession. In formulating the development plan, expanding employment and stabilizing employment should be regarded as an important goal. The "one-time employment rate" and "employment rate at the year-end" should be regarded as important contents of assessment so as to improve the implementation of the target responsibility system.

Perfect and Improve the Overall Quality of Individual Assessment of Students. After entering the freshman college, the first is a loss of mind does not know what to do in the future, what to do. This is a common problem faced by college students. Therefore, colleges and universities should start freshmen in the beginning, to cultivate students interested in learning professional and improve and perfect the overall quality of individual assessment of students, so that students can have a more comprehensive understanding of the school, can also be used as a basis for professional turn. As a student, you can also master some basic information about yourself, analyze yourself more clearly, and conduct macro analysis with micro data.

The key to ensure the quality of college students' employment guidance courses is to strengthen the construction of employment guidance faculty. Establish a more stable, high-quality, professional and professional teachers. (1) Invite professionals, successful people and heads of human resources department as part-time teachers frequently, hold special lectures and hold relevant activities to enhance employment awareness so that students in institutions can have higher employment awareness and employment crisis sense. (2) Formulating the training plan for employment guidance teachers, and actively encouraging them to participate in the training and qualification evaluation of career instructors and gradually obtain employment guidance certificates; (3) Relevant courses 
should be opened and a certain credit will be awarded after passing the grade, such as college career planning and career.

Cultivate Employment Awareness and Strengthen Career Planning Counseling. Career planning counseling should be from the perspective of personnel training in colleges and universities and the social requirements of the basic quality of personnel, combined with the professional and individual characteristics of students to determine the specific teaching content. During the career guidance period, Career Guidance Course will be set up to help students improve their job search skills and abilities. A professional with or without the market, with or without vitality, how much demand, on the quality of qualified personnel have any special requirements, we must through the social needs of personnel research and analysis to draw conclusions, which is set in colleges and universities to set what kind of professional, what kind of settings curriculum system, design what kind of personnel training mode, training what kind of talent and other aspects of feasibility prediction and scientific decision-making of the basic work. Do a good job in this school, schools can be based on the needs of the country in a timely manner to set up specialty disciplines and social urgently needed professional training of the urgent need of talent

In short, under the current economic situation, the career guidance for college students has stood at a new historical starting point. The situation is grim, the tasks are arduous and the responsibilities are heavy. Colleges and universities should continue to adjust the ideas and countermeasures of vocational guidance work to enhance the employment of university students core competitiveness, go all out to do a good job under the current economic situation of employment guidance for college graduates from the source to solve the fundamental problem of college graduates employment.

\section{References}

[1] Do not be proud of. Research teaching and its implementation requirements[J]. Chinese University Teaching 012.264 (8): 10-12.

[2] Alderson, J. C, \& W Website Does Wash back Existm Applied Linguistics, 1996, 14 (2)

[3] Labor and Social Security Training and Employment Department and China Employment Training Technology Center. Innovative career guidance new concept[M]. China Labor and Social Security Publishing House, 2005

[4] Liu Shiyong, Yang Yang. Employment guidance in Chinese colleges and universities professionalization of the status quo and trend development[A]. Chinese college students employment, 2008 (4)

[5] Zhao Tiesheng, Gou Zengqiang. Higher vocational college students' employment status quo and vocational guidance[A]. Career Circle, 2007 (3)

[6] Hua Jun, He Xianyang. Vocational Guidance Work Status Analysis and Countermeasures[A]. Yangzhou Vocational University, 2007 (9) 